Volume 13

\title{
Salutogenesis and the Prevention of Social Death: Cross-Cultural Lessons from Genocide-Impacted Rwandans and Indigenous Youth in Canada
}

Jobb D. Arnold

Canadian Mennonite University

Follow this and additional works at: https://digitalcommons.usf.edu/gsp

\section{Recommended Citation}

Arnold, Jobb D. (2019) "Salutogenesis and the Prevention of Social Death: Cross-Cultural Lessons from Genocide-Impacted Rwandans and Indigenous Youth in Canada," Genocide Studies and Prevention: An International Journal: Vol. 13: Iss. 3: 145-162.

DOI:

https://doi.org/10.5038/1911-9933.13.3.1682

Available at: https://digitalcommons.usf.edu/gsp/vol13/iss3/12

This Articles is brought to you for free and open access by the Open Access Journals at Digital Commons @ University of South Florida. It has been accepted for inclusion in Genocide Studies and Prevention: An International Journal by an authorized editor of Digital Commons @ University of South Florida. For more information, please contact digitalcommons@usf.edu. 


\section{Salutogenesis and the Prevention of Social Death: Cross-Cultural Lessons from}

Genocide-Impacted Rwandans and Indigenous Youth in Canada

\section{Acknowledgements}

This paper is dedicated to the memory of my friend Berthe Kayitesi and to all the survivors whose love and dedication to their chosen families and communities remains an inspiration. 


\title{
Salutogenesis and the Prevention of Social Death: Cross-Cultural Lessons from Genocide-Impacted Rwandans and Indigenous Youth in Canada
}

\author{
Jobb D. Arnold \\ Canadian Mennonite University \\ Winnipeg, Manitoba, Canada
}

\section{Introduction: Social Death and the Health of Group Life}

This paper sets out to explore community-based insights into genocide prevention by comparatively examining strategies for group survival developed in communities of Canadian-Indigenous youth and Rwandan student genocide survivors. ${ }^{1}$ Of course there are many profound differences in the circumstances that led to these genocides. The Rwanda genocide of 1994 occurred during a civil war and was ended by an absolute victory won by military forces that went on to form the current government - the Rwandan Patriotic Front (RPF). ${ }^{2}$ The colonial genocide of Indigenous Peoples on the Canadian Prairies unfolded in a different way. ${ }^{3}$ This comparative research is focused on psychosocial responses among genocide impacted youth. In particular, I am interested in the preventative capacity of communities to employ emergent and adaptive practices that foster resilience and allow healthy forms of group life to displace the pre-conditions of genocide. ${ }^{4}$

This work engages with philosopher Claudia Card's conception of social death which initiated what James Snow has described as a "radical shift in conceptualizing genocide" and an important step toward overcoming the "...fissure between the theorizing of genocide and the marginal[ized]... voices of witnesses and survivors of genocides." ${ }^{5}$ Card describes social death as the "...utter loss of freedom and control over one's vital interests [which] can be trans-generational and thus survive one's death. Before death, genocide victims are ordinarily deprived of control over vital transgenerational interests and more immediate vital interests." 6 This paper draws on periods of ethnographic research with the Association des Etudiants et Éleves Rescapés Du Genocide (AERG), as well as with a group of community leaders from an Urban Indigenous Village in Winnipeg, Canada. This research highlights the voices of Rwandans and Indigenous Peoples of Canada who have survived genocides and are organizing locally to address and transform the genocidal potentialities of social death they continue to confront on a daily basis. ${ }^{7}$

This paper flips the narrative of genocidal victimization and instead calls attention to insurgent and transitional practices that are generating emotionally charged inter-generational vitality. A key theme explored in the following section is how fighting social death requires promoting the social conditions that give rise to healthy forms of group life. Practices that promote a thriving group life are considered to be salutogenic - a term deriving from a combination of the latin salus (health) and the greek genesis (origin). In the latter sections, salutogenic dynamics are identified in the practices of cultural adaptation among young people who have been impacted by genocide in both Rwanda and Canada. This approach to genocide prevention promotes what social death

${ }^{1}$ In the Rwandan case study, names, places, and some information has been changed to protect the anonymity and confidentiality of research participants.

${ }^{2}$ Alison Des Forges, et al., "Leave None to Tell the Story": Genocide in Rwanda (New York: Human Rights Watch, 1999); Mahmood Mamdani, When Victims Become Killers: Colonialism, Nativism, and the Genocide in Rwanda (Princeton: Princeton University Press, 2001); Scott Straus, The Order of Genocide: Race, Power, and War in Rwanda (Ithaca: Cornell University Press, 2006).

${ }^{3}$ Andrew Woolford, et al., eds., Colonial Genocide in Indigenous North America (Durham: Duke University Press, 2014); A. Dirk Moses, ed., Empire, Colony and Genocide: Conquest, occupation, and Subaltern Resistance in World History (New York: Berghahn Books, 2008); Ned Blackhawk, Violence Over the Land: Indians and Empires in the Early American West (Cambridge: Harvard University Press, 2008).

${ }^{4}$ Aaron Antonovsky, “The Salutogenic Perspective: Toward a New View of Health and Illness," Advances 4, no.1 (1987), 47-55.

${ }^{5}$ James Snow, “Claudia Card's Concept of Social Death: A New Way of Looking at Social Death,” Metaphilosophy 47, no. 4-5 (2016), 608-628.

${ }^{6}$ Claudia Card, "Social Death and Genocide," Hypatia 1, no. 18 (2003), 73; Claudia Card, "Surviving Long-Term Mass Atrocities," Midwest Studies in Philosophy 36, no.1 (2012), 35-52, accessed February 14, 2019, Doi: 10.1111/j.14754975.2012.00232.x.

${ }^{7}$ Lee Ann Fujii, “Five Stories of Accidental Ethnography: Turning Unplanned Moments in the Field into Data," Qualitative Research 15, no. 4, (2015), 525-539, accessed February 14, 2019, Doi:10.1177/1468794114548945. 
assails: social vitality. For Card, "Social vitality exists through relationships, contemporary and intergenerational, that create an identity that gives meaning to a life." Social death isn't as much about killing as it is about the "major loss of social vitality," that in turn destroys positive identities and can result in "a serious loss of meaning for one's existence. ${ }^{8}$ Card's approach to understanding genocide "takes the focus off individual choice, individual goals, individual careers, and body counts, and puts it on relationships that create community and set the context that gives meaning to choices and goals." ${ }^{\prime 9}$

Such careful attention to the multiple-levels of intersecting-processes and perspectives has also been central to the development of colonial genocide scholarship. For instance, as Andrew Woolford observes, it has been "a disservice to force Aboriginal experiences of ecological destruction into a framework that acknowledges only the subsistence value of land to a group," when what is critically at stake in genocide is also the ontological destruction of the very essence of group life. ${ }^{10}$ Building on these and other micro-level analyses, this paper unpacks the theoretical underpinnings of salutogenic approaches that can be applied to thinking about genocide prevention efforts. These theoretical interventions largely underscore already existing community-based solutions that have demonstrated the capacity to prevent genocide and secure the foundations of group life on their own terms. The Canadian and Rwandan contexts differ tremendously and it is not my intention to compare suffering but rather to call attention to the ways that both communities have found ways to survive on their own term. Not only are these powerful examples of psychosocial resilience, they are strategic approaches to counter-acting social death. As Almedom and colleagues describe,

Psychosocial resilience encompasses a dynamic multidimensional set of personal capabilities as well as social and material assets/resources that individuals, families, and communities mobilize to mentally and emotionally embrace "turbulent" change and transformation while maintaining routine functioning without loss of identity, integrity, or core purpose in life that defines them as who they are individually as well as collectively. ${ }^{11}$

The latter part of this paper incorporates first-hand accounts from Rwandan and Canadian genocide survivors. The struggles described by community members exemplify the ongoing contest between the forces of social death and those of group life. In both the Rwandan and Canadian contexts, social alignments based on mutual aid, chosen kinship, and collective ritual are all important features of genocide prevention. These three powerful community-level genocide prevention strategies mobilize a framework that takes into account key findings from research that has focused on locallevel sensibilities of coherence as a basis for resilience. ${ }^{12}$

\section{Stimulating Salutogenic Displacement of Social Death}

As a branch of "positive psychology" salutogenesis, like much genocide scholarship, builds on insights from survivors of the Holocaust. Victor Frankl perceived that,

Those who know how close the connection is between the state of mind of a man - his courage and hope, or lack of them - and the state of immunity of his body will understand that the sudden loss of hope and courage can have a deadly effect." 13

\footnotetext{
${ }^{8}$ Card, Social death, 63 .

${ }^{9}$ Ibid., 74.

${ }^{10}$ Andrew Woolford, “Ontological Destruction: Genocide and Canadian Aboriginal Peoples," Genocide Studies and Prevention 4, no.1 (2009), 81-97.

${ }^{11}$ Astier M. Almedom, et al., "Principles of Epistemological Accountability with Methodological Implications for Measuring, Assessing, and Profiling Human Resilience," Ecology and Society 20, no. 3 (2015), 9, accessed November 11, 2017, Doi: 10.5751/ES-07313-20030.

${ }^{12}$ Astier Almedom, "Resilience, Hardiness, Sense of Coherence and Post-Traumatic Growth. All Paths Leading to 'Light at the End of the Tunnel?'” Journal of Loss and Trauma 10, no. 3 (2005), 253-265, accessed January 21, 2019, Doi: 10.1080/15325020590928216; Astier M. Almedom, et al., "Use of 'Sense of Coherence (SOC)' Scale to Measure Resilience in Eritrea: Interrogating both the Data and the Scale," Journal of Biosocial Science, 39 (2007), 91-107.

${ }^{13}$ Victor E. Frankl, Man's Search for Meaning: An Introduction to Logotheraphy, 4th ed., trans. Ilse Lasch (Boston: Beacon Press, 1992), 84.
} 
What Frankl knew from his own experiences he expressed by paraphrasing Nietzsche's famous aphorism "he who knows the 'why' for his existence ... will be able to bear almost any 'how."'14 Frankl developed and applied the insights he gained from his experiences in the Nazi concentration camps through his "meaning centered" approach to clinical psychotherapy called "Logotherapy."15 Antonovsky, in contrast, pursued a more systematic approach to public health among genocide survivors. Antonovsky grounded these research questions in the day-to-day practices of Jewish Holocaust survivors living in Israel, who had been able to thrive in spite of, and in some cases because of, their experiences. These early studies of human health responses to trauma helped pave the way for what is now a significant body of evidence documenting salutary and transformative experiences among survivors of violence sometimes referred to as "post-traumatic-growth."16

Promoting salutogenesis can be understood as a process of essentially reverse engineering the "utter loss of freedom and control over one's vital interests" characteristic of social death. Social death takes hold when the conditions needed for healthful group life are undermined by fear, uncertainty and despair. Conversely, for Antonovsky "the origins of health are to be found in a sense of coherence." ${ }^{17}$ An individual's sense of coherence according to Antonovsky refers to

a global orientation that expresses the extent to which one has a pervasive, enduring though dynamic feeling of confidence that (1) the stimuli deriving from one's internal and external environments in the course of living are structured and predictable, and explicable; (2) the resources are available to one to meet the demands posed by these stimuli; and (3) these demands are challenges, worthy of investment and engagement. ${ }^{18}$

This three-part sense of coherence construct has been used as the basis for a quantitative 28-item "sense of coherence scale" as well as a shorter 13-item version. ${ }^{19}$ This approach understands human health as a "dynamic-steady state" that exists on a spectrum of ease to dis-ease. There are three sub-components to Antonovsky's coherence model that reflect key domains associated with salutogenesis: comprehensibility, manageability, and meaningfulness. Cross-cultural findings using sense of coherence measures have been influential in the fields of global health, establishing that these three dimensions of coherence are valid indicators of durable forms as social vitality and long-term resilience. ${ }^{20}$ Recognizing that hope, healing and transformation can and do co-occur on a spectrum that includes despair, violence and uncertainty is itself an important step toward preventing genocide..$^{21}$

\section{Orienting the Micro-Foundations of Genocide Prevention}

In the introductory essay to the extensive reader on genocide scholarship Jens Meierhenrich describes the "emphasis on the micro-foundations of genocidal violence" as being of the "utmost importance for second-generation scholars of comparative genocide." 22 While Meierhenrich's review does not

\footnotetext{
${ }^{14}$ Ibid., 88 .

${ }^{15}$ Ibid., 108.

${ }^{16}$ Richard G. Tedeschi, et al., eds., Post Traumatic Growth: Positive Change in the Aftermath of Crisis (New York: Psychology Press, 2008).

${ }^{17}$ Aaron Antonovsky, Health, Stress, and Coping (London: Jossey-Bass Publishers, 1980), vii.

${ }^{18}$ Antonovsky, The Salutogenic, 19.

${ }^{19}$ Almedom, et al., Use of Sense of Coherence (SOC) Scale.

${ }^{20}$ Bengt Lindstrom and Monica Eriksson, "Contextualizing Salutogenesis and Antonovsky in Public Health Development," Health Promotion International 21, no. 3 (2006), 228-235, accessed September 21, 2017, doi: 10.1093/ heapro/dal016; Bengt Lindström and Monika Eriksson, "Salutogenesis," Journal of Epidemiology and Community Health 59, no.6 (2005), 440-442.

${ }^{21}$ John Parker, et al., "'Hope Is the Engine of Life', 'Hope Dies with the Person': Analysis of Meaning Making in FAO Supported North Caucasus Communities Using the 'Sense and Sensibilities-of-Coherence' (SSOC) Methodology," Journal of Loss and Trauma 18, no. 2 (2013), 140-151, doi: 10.1080/15325024.2012.684578; Peter Suedfeld, "Reactions to Societal Trauma: Distress and/or Eustress," Political Psychology 18 (1997), 849-861.

${ }^{22}$ Jens Meierhenrich, "Introduction: The Study and History of Genocide," in Genocide: A Reader, edited by Jens Meierhenrich (Oxford: Oxford University Press, 2014), 27.
} 
include examples from the salutogenesis literature, the sense of coherence approach offers insights into the mobilizing orientation behind political violence as well as the psychological capacity to resist and overcome these oppressive and destructive forces. ${ }^{23}$

Antonovksy's early work on the origins of health after genocide took place at a historical moment when the intensification of settler colonial processes in Israel were ramping up systemic displacement, exclusion, and violence against Palestinians in the occupied territories. ${ }^{24}$ For Antonovsky, the health of the Israeli state seems necessarily embodied in the shared coherence of individual Israeli settlers. In the preface to his landmark 1979 study "Health, Stress and Coping," Antonovsky describes his friend, colleague and Israeli settler, Abraham David Katz, as someone, who "more than anyone I've ever known, embodied what I later came to call the sense of coherence. Unhappily," Antonovsky continues, "David Katz... was killed at the Suez Canal in the Yom Kippur War." ${ }^{25}$ Katz demonstrates that someone's personal coherence does not prevent them from fighting and killing in war, and suggests it likely helped align and cohere groups of Israeli soldiers who understood themselves as fighting to secure the conditions of collective survival for their people. Local-level violence is always mediated by the ways that groups of people comprehend situations, manage collective responses, and make meaning when they feel that their survival is pitted against that of another ethnic, religious, or political group.

The relevance of engaging genocide prevention at the level of community coherence is highlighted in Lee Ann Fujii's study of the neighborly dynamics of genocide in Rwanda. In order to understand public violence Fujii calls attention to the ways that complex social interactions are mediated by relationships that can either facilitate or prevent instances of direct violence and killing. As Fujii describes it,

Genocide as a process becomes a temporal and spatial unfolding of ambiguous actions, shifting contexts, and actors with multiple contradictory motives ... Viewing actors dynamically allows us to probe a broad range of people's behaviour during the genocide, with its attendant contradictions, ambiguities, without the need to box actors into the standard categories of 'victim,' 'perpetrator,' 'bystander' or 'rescuer. ${ }^{26}$

Community relationships can create, maintain, or prevent locally relevant "alternative pathways to violence" from forming. ${ }^{27}$ When seeking to prevent genocide it is important to become sensitive to the ways that meanings shapeshift across local contexts, creating shared understandings and mutually intelligible feelings. In other words, it is essential to account for the fact that in addition to cognitive understanding, meaning is also felt.

In the decades since Antonovsky's original work, salutogenic research has expanded greatly with increased attention to both the gender and affective dynamics of day-to-day life. Eritreanborn, Oxford-educated biological anthropologist Astier Almedom has contributed immensely to the study of salutogenesis. In particular, Almedom's work calls much needed attention to the ways that gender and affect are involved at all levels of community crisis response including activities of genocide prevention. ${ }^{28}$ Almedom's work extends and deepens Antonovsky's model by incorporating qualitative analysis including attention to the role of women and emotional labor

\footnotetext{
${ }^{23}$ Sarah Abu-Kaf, et al., "Youth in the Midst of Escalated Political Violence: Sense of Coherence and Hope among Jewish and Bedouin Arab Adolescents," Child and Adolescent Psychiatry and Mental Health 11, no. 1 (2017), 1-10, accessed September 25, 2019, Doi: 10.1186/s13034-017-0178-z; Peter Suedfeld, “Homo Invictus: The Indomitable Species" Canadian Psychology/Psychologie Canadienne 38, no. 3 (1997), 164-173, accessed November 21, 2018, Doi: 10.1037/0708-5591.38.3.164.

${ }^{24}$ Damien Short and Haifa Rashed, "Palestine," in Redefining genocide: Settler Colonialism, Social Death and Ecocide, ed. Damien Short, 68-92 (London: Zed Books, 2016); Ariella Azoulay and Adi Ophir, "Abandoning Gaza," in Agamben and colonialism, ed. Marcelo Svirsky and Simone Bignall (Edinburgh: Edinburgh University Press, 2012), 178-203.

${ }^{25}$ Antonovsky, Health, Stress, and Coping.

${ }^{26}$ Lee Ann Fujii, Killing Neighbours: Webs of Violence in Rwanda (Cornell: Ithaca, 2009), 11.

${ }^{27}$ Ibid., 188.

${ }^{28}$ Almedom, et al., Principles of Epistemological, 9.
} 
in orienting and sustaining local-level sensibilities of coherence. ${ }^{29}$ Almedom's work marks a shift to a sensibilities of coherence model that incorporates analyses of the powerful affective energies generated in the face of existential threats.

The importance of feelings is certainly not a new domain of knowledge, as Tanana Athabascan scholar Dian Million points out "academia repetitively produces gatekeepers" that prevent Indigenous women "entry into important social discourses because we feel our histories as well as think them." ${ }^{30}$ For Million "A felt analysis is one that creates a context for a more complex telling." 31 In recent instances of colonial genocide against Indigenous Peoples, Million notes that it wasn't until First Nation's men and women shared their personal testimony of sexual and other forms of abuse that Canada was put under "an international spotlight for genocidal child abuse spanning a century." 32 New sensibilities of coherence emerged thanks to "Native women's personal narratives [that] explored the racialized, gendered, and sexual nature of their colonization." 33 As these narratives circulated throughout Canada they brought untold histories and unheard voices to the surface in ways that "transformed the debilitating force of an old social control, shame, into a social change agent in their generation." 34

Similarly, complex types of mobilized affective dynamics have been part of reorienting the social emotional dynamics connected to the Rwandan genocide. For many Rwandans, local sensibilities of coherence are encoded in parables and allegory. As Rwandan-Canadian Psychiatrist Deogratias Bagalyshia describes,

Rwandan tradition provides a set of popular beliefs and practices to which the people of Rwanda often turn in difficult situations and times of great distress... The proverb creates a bridge between emotions, feelings or states of mind suffered at difficult moments, and the appropriate attitude prescribed by Rwandan tradition, to surmount the difficulties caused by this trying situation." ${ }^{\prime 35}$

These culturally embedded expressions are part of the community-level sensibilities of coherence in both Canada and Rwanda. These ways-of-knowing the world also inform the relationships that give form to the affinities and aversions that exist in regional networks. Preventing genocide requires incorporating emotionally and culturally coherent analyses that attend to the ways that perceived threats are likely to evolve during periods of social uncertainty. Turning to the field of Cultural Studies provides some useful ways of conceptualizing and exploring how how analyzing affective dynamics of these local conditions can inform critical genocide prevention.

\section{Emergent Prevention and the Structure of Feeling}

The work of cultural theorist Raymond Williams is helpful in seeing how feelings are involved in constituting the foundations of group-life. Feelings give shape to latent patterns of social behavior before they are fully manifest. These preconditions exist as emergent culture. For Williams, "What matters finally in understanding emergent culture ... is that it is never only a matter of immediate practice. Indeed, it depends crucially on finding new forms of adaptation of form." ${ }^{36}$

This is a critical insight for genocide prevention. The preconditions of overlap with the preconditions for its prevention; both involve profound "adaptations of form" which give rise to shared identities and challenge relations of power. Embedded local actors are sensitive to these conditions of "pre-emergence" in ways that enable them to respond to subtle contingencies

\footnotetext{
${ }^{29}$ John Parker, et al., Hope Is the Engine of Life.

${ }^{30}$ Dian Million, “Felt Theory: An Indigenous Feminist Approach to Affect and History,” Wicazo Sa Review 24, no. 2, (2009), 53-76.

${ }^{31}$ Ibid., 54 .

${ }^{32}$ Ibid.

${ }^{33}$ Ibid.

${ }^{34}$ Ibid.

${ }^{35}$ Deogratias Bagalyshia, "Mourning and Recovery from Trauma: In Rwanda, Tears Flow Within," Transcultural Psychiatry, 37, no. 3 (2000), 337-353.

${ }^{36}$ Raymond Williams, Marxism and Literature (Oxford: Oxford University Press, 1977), 126-127.
} 
that would be missed by outsiders. Such sensitivity is a necessary part of both identifying and working toward displacing the immediate conditions of social-death. When the preconditions for salutogenesis are undermined this creates the conditions for uncertainty that can create regional power vacuums and lead to for escalatory spirals of conflict. Power vacuums also undermine the spirit of local resistance, making it more possible for genocidal-orders to emerge and allowing the conditions of social death to spread unabated. Accounting for these qualitative tipping-points requires sensitivity to the relative stability and affective intensity of constantly evolving life-anddeath scenarios.

The potentialities of day-to-day life change with the rising and falling of affect. Affect refers to life's emotional energies set in motion publicly and in ways that either increase or decrease individual and collective capacities for action. ${ }^{37}$ Williams' critical insight for genocide prevention is that "what we have to observe is in effect a pre-emergence, active and pressing but not yet fully articulated, rather than the evident emergence;" we must, says Williams "explore the concept of structures of feeling." ${ }^{38}$

When ontological destruction is occurring, political issues are immediately seen for what they are: matters of life and death. As AIDS activist and social movement scholar Deborah Gould writes, "emotion incites, shapes, and is generated by practices of meaning-making." ${ }^{39}$ Gould describes the shared identities that are forged amidst such existential struggle as "affective ontologies" given shape by the mobile affective energies that infuse and inform daily ways-of-being-in-the-world. ${ }^{40}$ Naming and responding to things that can kill can be a powerful way to clarify and amplify local sensibilities of coherence. Putting emotionally charged discourses into local circulation can influence collective behavior by creating social alignments in response to collective threats. As emotionally "sticky" tropes circulate through conflicted spaces they stick to people who relate to the manner of expression given to shared feelings often presented as politicized tropes, giving them greater currency, and more exclusionary weight, among identity-based communities. These affective economies are important to mobilizing exclusionary practices, polarizing groups, and intensifying local-level antagonisms. ${ }^{41}$

These dynamics are significantly amplified through social media channels. ${ }^{42}$ As defense analyst John Arquilla notes, there has been a paradigmatic shift in the relative power of networks and nations across the globe - a shift that has important implications for genocide prevention. ${ }^{43}$ The power of networks creates new potential for approaches to genocide prevention that engage the dynamics of transformational mass participation. ${ }^{44}$ Enabled and amplified through digital communications technologies, networked social alignments can create new pathways to action. Affective coherence is critical to both orienting and activating small groups either on to, or off of pathways that lead to genocidal violence. This requires understanding the emotional attachments that align individuals with a perceived collective.

Sara Ahmed writes that,

Rather than seeing emotions as psychological dispositions, we need to consider how they work, in concrete and particular ways, to mediate the relationship between the psychic and the social, and between the individual and the collective ... emotions work by sticking figures together (adherence), a sticking that creates the very effect of a collective (coherence). ${ }^{45}$

\footnotetext{
${ }^{37}$ Melissa Gregg and Gregory J. Seigworth, "An Inventory of Shimmers," in The Affect Theory Reader, ed. Melissa Gregg and Gregory J. Seigworth (Durham: Duke University Press, 2010), 1-28; Ruth Leys, "The Turn to Affect: A Critique," Critical Inquiry 37 (2011), 434-473.

${ }^{38}$ Ibid., 127.

${ }^{39}$ Ibid., 13.

${ }^{40}$ Deborah B. Gould, Moving Politics: Emotion and ACT UP's Fight Against AIDS (Chicago: University of Chicago Press, 2009).

${ }^{41}$ Sara Ahmed, "Affective Economies," Social Text, 51 (2004), 119.

${ }^{42}$ Zeynep Tufecki, Twitter and Tear Gas: The Power and fragility of networked protest (New Haven: Yale University Press, 2017).

${ }^{43}$ John Arquilla, "Of Networks and Nations," The Brown Journal of World Affairs 14, no. 1 (2007), 199-205.

${ }^{44}$ Zeynep Tufecki and Christopher Wilson, "Social Media and the Decision to Participate in Political Protest: Observations from Tahrir Square," Journal of Communication 62 (2012), 363-379.

${ }^{45}$ Ahmed, Affective Economies, 119.
} 
Approaching genocide prevention through a sensibilities of coherence lens can help identify local thresholds of violence that exist along un-fixed affective edges in ways that can inform how more spatially fixed local boundaries are understood. Such increased nuance helps to account for the ambiguity and ambivalence that can characterize conflicts where ethno-religious political divisions alternate back and forth between being more-or-less fluid or frozen identity groupings. ${ }^{46}$ Understanding the constitutive role of affective forces within social-networks also can help account for the reasons why some people find it extremely difficult to escape the immediate conditions of social death. ${ }^{47}$ Finding points of shared understanding and felt solidarity can create a basis for shifting the affective valence in an entire community. Strategies of prevention based on affective alignment may also enhance survival opportunities for community members when navigating complex and shifting local conflict conditions including the threat-multiplying effects of climate change.

The Rwandan and Indigenous-Canadian communities case studies examined in the following sections demonstrate cross-cultural practices that illustrate elements of both emergent culture and affective mobilization. First hand descriptions from genocide survivors provide an indication of how these community groups have oriented their own local organizing toward both preventing and surviving genocidal conditions. Finding ways of leveraging the affective force needed to displace the dynamics of social death represents an ongoing challenge and opportunity for genocide prevention studies.

\section{Family, Villages, and the Salutogenic Quality of Kinship}

Few levels of analysis more directly indicate the health or illness of regional group life than the day-to-day conditions of life for children. The extensive intergenerational trauma and broken social bonds related to genocide have destroyed many biological families in both Rwanda and among Indigenous communities in Canada. The deadly long-term consequence of colonial policy starkly illustrates Card's insight, already cited, that "genocide victims are ordinarily deprived of control over vital trans-generational interests and more immediate vital interests." 48

The central place of children in-group life is clearly indicated in Article 2 of the Genocide Convention outlining the different ways that group life is targeted through acts aimed at children. ${ }^{49}$ In both Rwanda and Canada attacks on children and culturally important kinship networks were foundational to the character of the genocidal assaults on group life. Indigenous youth in Canada became dislocated from their land-based ways of life, kinship relations and cultural teachings as a result of settler colonialism. The Indian Residential School system and subsequent versions of Canadian child welfare policy epitomize the colonial focus on assimilating or eradicating Indigenous group life generationally. In Rwanda, webs of community and familial relations that were once a source of help became a deadly hindrance when the intensity of full-blown genocidal killing took hold of the hills.

The research literature on the psychosocial impacts of war and genocide on children has understandably been focused on the pathogenic outcomes that these horrific processes have on children's lives and the long-term impacts on their future chances in life. However, in her 2005 review of the resilience literature Almedom notes that "anthropological insight into children's

\footnotetext{
${ }^{46}$ Jennifer Todd, et al., "Fluid of Frozen? Change in Ethno-National Identification in Contemporary Northern Ireland," Nationalism and Ethnic Politics 12 (2005), 323-346.

${ }^{47}$ Loï Wacquant, et al., "Territorial Stigmatization in Action," Environment and Planning 46 (2014), 1-11.

${ }^{48}$ Card, Social death, 73; See also, Claudia Card, “Surviving Long-Term Mass Atrocities," Midwest Studies in Philosophy 36, no.1 (2012), 35-52, accessed August 21, 2017, Doi: 10.1111/j.1475-4975.2012.00232.x.

${ }^{49}$ United Nations, General Assembly Resolution 260, Convention on the Prevention and Punishment of the Crime of Genocide, December 9, 1948 (UN Doc. A/RES/260(III)), article 2. This article explains as follows:

Article 2:

(a) Killing members of the group;

(b) Causing serious bodily or mental harm to members of the group;

(c) Deliberately inflicting on the group conditions of life calculated to bring about its physical destruction in whole or in part;

(d) Imposing measures intended to prevent births within the group;

(e) Forcibly transferring children of the group to another group.
} 
experiences cautions against the (pathogenic) 'universalist' and 'apocalypse' models, respectively, of childhood and war." ${ }^{50}$ As an alternative, Almedom advocates for greater inclusion of "combined models of risk and resilience involving narrative approaches" which contribute to "building children's sense of coherence, self-efficacy, and resilience." ${ }^{51}$ Such community practices have the capacity to displace social death and cultural destruction with Indigenous-led ways of being-inthe-world that promote what Cindy Blackstock describes as "cultural perpetuity. ${ }^{52}$

Community-Led Organizing in Winnipeg's Urban Indigenous Village

The prairie city of Winnipeg, Canada has a population of 800,000 people including a large Indigenous community. Indeed, Winnipeg has the largest urban Indigenous population of any city in Canada, with over 90,000 Peoples from Cree, Ojibwe, Oji-Cree, Dakota, Dené, Inuit, and Red River Métis backgrounds. For many Indigenous youth living in Winnipeg their conditions of dayto-day survival are deeply entangled in systems connected to the ongoing traumas of colonization and in particular, the Indian Residential Schools (IRS) system.

Policies of territorial dispossession, apprehension, and transfer of Indigenous children, and the criminalization of traditional land-based spirituality were all efforts intended to inflict "conditions of life calculated to bring about its physical destruction in whole or in part." 53 These genocidal realities remain embedded in neo-colonial government institutions that McCallum and Perry describe as "structures of indifference." ${ }^{54}$ Indeed, trans-generational transmission of trauma associated with dispossession from traditional territories, destruction of language and culture, and child apprehensions all continue to contribute to poor Indigenous health. ${ }^{55}$ Canada's Truth and Reconciliation Commission has called "upon the federal, provincial, territorial, and Aboriginal governments to acknowledge that the current state of Aboriginal health in Canada is a direct result of previous Canadian government policies." ${ }^{56}$ Indeed, the presence of negative "social determinants of health" including high levels of incarceration, rampant suicide, and exposure to disproportionate levels of violence all converge to support the thesis that social death continues to be a genocidal threat to Indigenous peoples. ${ }^{57}$

The bleak fact is that twenty-years after the last IRS closed the Canadian child welfare system had more Indigenous youth in care than at the height of IRS operations. ${ }^{58}$ Indigenous youth make up nearly 90 percent of youth in state foster care. This translates into more than ten thousand Indigenous young people who have been removed from their homes and separated from their families. These youth "in care" are case-managed as wards of the Canadian state, living in arrangements that vary widely, although some of the broadest pathways available lead directly to

\footnotetext{
${ }^{50}$ Almedom, All paths, 259.

${ }^{51}$ Ibid., 260.

${ }^{52}$ Cindy Blackstock, "Revisiting the Breath of Life Theory," The British Journal of Social Work 49, no.4 (2019), 854-859, accessed October 2, 2019, Doi:10.1093/bjsw/bcz047.

${ }^{53}$ Michael J. Chandler and Christopher Lalonde, "Cultural Continuity as a Hedge Against First Nations Suicides in Canada," Transcultural Psychiatry 35, no. 2 (1998), 191-219; Teresa Evans-Campbell, "Historical trauma in American Indian/Native Alaska communities: A Multilevel Framework for Exploring Impacts on Individuals, Families, and Communities," Journal of Interpersonal Violence 23 (2008), 316-338; Tony Barta, "Relations of Genocide: Land and Lives in the Colonization of Australia," in Genocide and the Modern Age, 2nd ed., ed. Michael N. Wallimann and Isidor Dobkowski (Syracuse: Syracuse University Press, 2000), 237-252.

${ }^{54}$ McCallum and Perry, Structures of Indifference

${ }^{55}$ Robert Nesdole, et al., "Reconceptualizing Determinants of Health: Barriers to Improving the Health Status of First Nations Peoples," Canadian Journal of Public Health 105, no. 3 (2014), 209-213.

${ }^{56}$ Truth and Reconciliation Canada, Honouring the Truth, Reconciling for the Future: Summary of the Final Report of the Truth and Reconciliation Commission of Canada (Winnipeg: Truth and Reconciliation Commission of Canada, 2015).

${ }^{57}$ Standing Committee on Indigenous and Northern Affairs and Canadian Parliament, Breaking Point: The Suicide Crisis in Indigenous Communities: Report of the Standing Committee on Indigenous and Northern Affairs (Ottawa: House of Commons, 2017), accessed November 2, 2018, http://www.ourcommons.ca/Content/Committee/421/INAN/Reports/ RP8977643/inanrp09/inanrp09-e.pdf.

${ }^{58}$ Cindy Blackstock, "Reconciliation means not saying sorry twice: Lessons from Child Welfare in Canada," in From Truth to Reconciliation: Transforming the Legacy of Residential Schools, ed. M.B. Castellano, et al. (Ottawa: Dollco Printing, 2008), 163-178.
} 
adverse social determinants of health. ${ }^{59}$ These overlapping and interlocking cycles coupled with intensive surveillance and interference by government agents in community-level responses has deprived many Indigenous Peoples of the capacity to care for their own children.

This situation regarding Indigenous youth in care has become recognized by all parties involved as untenable. While governments continue to flounder, community-leaders are advocating responses that can be understood as re-establishing local sensibilities of coherence. In Winnipeg, "The Village" has become a common referent, which encompasses a variety of local solutions to a plethora of community-specific problems. The Village does the work of creating salutogenic conditions for the youth, and in so doing, directs vital energy away from the domains of social death, and toward the aims of life

It's the Village's role to take care of the children ... If we want to change what's happening with children that's going to have to come from us. So that means we have to help our neighbors. That means we have to help our relatives. That means we get to work on being good parents, good uncles, good aunties. But not just for our family but also for the people who live beside us, and for our whole community. ${ }^{60}$

Michael Redhead Champagne is an Indigenous organizer and advocate who started an antiviolence initiative Meet Me at the Bell Tower in 2011. Having grown up in Winnipeg, Champagne is acutely aware of day-to-day experiences of street violence, racialized policing, child apprehensions, sexual exploitation, suicide, and addictions that exist within his community ${ }^{61}$ Champagne is an advocate of Winnipeg's urban Indigenous-led, "Village." "The Village," as it is referred to locally, is a network of urban Indigenous people and their allies living in and around Winnipeg. The concept builds on existing Indigenous culture and includes strengthening local knowledge through the revival of kinship networks, clan systems, and Indigenous languages. ${ }^{62}$ Taken together, these local practices create capacity for community healing, and cultural perpetuity. The aims of the Village can be understood as preventing social death by fostering salutogenic relationships held together by locally relevant sensibilities of coherence.

Working with other groups within The Village has enabled networked responses through which communities can influence the conditions that impact on their own well being. These networks amplify community capacities; when people come together for events like Meet Me at the Bell Tower, they become part of

creating safe spaces for people to share their opinions and their perspectives and their lessons. It's an opportunity for citizens to see their power. And because it's not often attended to - and it's never operated on by elected officials - the community gets to see what we as citizens can do when we organize ourselves ... It enriches our community ${ }^{63}$

Youth raised in the child welfare system in Manitoba are more likely to experience gang related violence and to become ensnared in the sex trafficking industry. ${ }^{64}$ These factors have also been identified as contributing to the genocidal phenomena of Missing and Murdered Indigenous Women and Girls. The Canadian national commission that was struck to investigate the circumstances surrounding these disappearances and deaths found that these outcomes were part of the ongoing

${ }^{59}$ Brian Giesbrect, “TRC Call to Action \#1: Child Welfare," Frontier Centre for Public Policy, November 4, 2018, accessed January 5, 2019, https://fcpp.org/2018/11/04/trc-call-to-action-1-child-welfare/.

${ }^{60}$ Champagne, discussion, December 12, 2015.

${ }^{61}$ Aboriginal Youth Opportunities, "Opportunities," accessed January 10, 2019, https://www.ayomovement.com/.

${ }^{62}$ Kino-nda-niimi Collective, ed., The Winter We Danced: Voices from the Past, the Future, and the Idle No More Movement (Winnipeg: ARP Books, 2014).

${ }^{63}$ Champagne, discussion, December 12, 2015.

${ }^{64}$ Elizabeth Comack, et al., "Indians Wear Red": Colonialism, Resistance, and Aboriginal Street Gangs (Halifax: Fernwood Publishing, 2013); Robert Chrismas, "Modern Day Slavery and the Sex Industry: Raising the Voices of Survivors and Collaborators While Confronting Sex Trafficking and Exploitation in Manitoba, Canada" (Ph.D. diss., University of Manitoba, 2017), accessed January 2, 2019, https://mspace.lib.umanitoba.ca/bitstream/handle/1993/32586/CHRISMAS, Robert PHD THESIS.pdf? sequence $=45$. 
genocide against Indigenous Peoples. ${ }^{65}$ Genocide prevention in such contexts requires direct forms of community-led intervention.

Champagne grew up in the child welfare system and has become a leading voice calling for community-led responses to the government's child welfare policy by mobilizing his community to become the village that children need.

The Village has to engage with every single level of government. The Village is critical in building up people's institutional knowledge to know and understand which jurisdiction, which level of government is required to implement which solution... So what that does is it forces the grassroots community to examine: what is the role [of] these different jurisdictional bodies, or these governments in the solutions that we are beginning to implement right now because we're not waiting. I don't have faith in the government-led process. I don't really have faith in the government, period. We've got to save ourselves. ${ }^{66}$

Winnipeg's "Village" exercises forms of digital sovereignty through its extensive communications network, a strong social media presence, and the use of internet memes in rearticulating dimensions of culture and identity. ${ }^{67}$ This enables information sharing, maintaining connections, live streaming difficult encounters, coordinating resources, and mobilizing collective actions. ${ }^{68}$ As Champagne puts it, "The advantage of the Village is its fluidity." ${ }^{69}$

Village sensibilities of coherence help to cohere relationships that exist both online and offline. This has generated a network of "topological relations," a development also noted in the anthropological observation that villages have moved past being "bounded units" and are now seen as topological "places enmeshed within amorphous realities significantly characterized by the circulation of people, goods, images, and ideas not moored to any single place." ${ }^{\prime 70}$ In Winnipeg social media channels have created many opportunities for urban Indigenous youth to reconnect with local land-based ceremonies and cultural teachings. These topological connections have been significant in the rise of Winnipeg's Village and have created what Shields and colleagues describe as new ecologies of affect..$^{71}$ These changing relational dynamics are transforming the preconditions of genocide and salutogenic growth.

\section{New Families: Chosen Kinship and Mutual Aid Among Rwandan Student Genocide Survivors}

Ten years after the 1994 genocide approximately 17 percent of Rwandan youth under the age 18 were orphans. ${ }^{72}$ The reasons for the children becoming orphaned include "the 1994 genocide, later massacres, imprisonment of adults accused of genocide and HIV/AIDS."73 In total, it is estimated that there are between 65,000 and 227,500 Youth-Headed Households (YHH) in Rwanda. ${ }^{74}$ Research into the day-to-day conditions of over 690 Rwandan orphans indicated that 52 percent felt their relatives took advantage of them. Even more indicated they did not trust their relatives to look out

\footnotetext{
${ }^{65}$ National Inquiry into Missing and Murdered Indigenous Women and Girls, Reclaiming Power and Place: The Final Report of the National Inquiry into Missing and Murdered Indigenous Women and Girls, Volume 1a, accessed July 21, 2019, https:// www.mmiwg-ffada.ca/wp-content/uploads/2019/06/Final Report Vol 1a-1.pdf.

${ }^{66}$ Champagne, discussion, December 12, 2015.

${ }^{67}$ Ryan Frazer and Bronwyn Carlson, "Indigenous Memes and the Invention of a People," Social Media Society 3, no. 4 (2017), accessed April 9, 2018, Doi: 10.1177/2056305117738993.

${ }^{68}$ The issue of surveillance and the role of the internet in contemporary genocide is an important and related issue that goes beyond the scope of this paper. For a relevant discussion of some of the implications of "total information awareness" see, Bernard E Harcourt, The Counterrevolution: How Our Government Went to War against Its Own Citizens (New York: Basic Books, 2018).

${ }^{69}$ Champagne, discussion, December 12, 2015.

${ }^{70}$ Antonio Sorge and Jonathan Padwe, "The Abandoned Village? Introduction to the Special Issue," Critique of Anthropology 35, no. 3 (2015), 242, accessed June 20, 2018, Doi: 10.1177/0308275X15588618.

${ }^{71}$ Rob Shields, et al., Ecologies of Affect: Placing Nostalgia, Desire, and Hope (Waterloo: Wilfrid Laurier University Press, 2011).

${ }^{72}$ Tonya R. Thurman, et al., "Psychosocial Support and Marginalization of Youth-Headed Households in Rwanda," Aids Care 18, no. 3, (2006), 220-229, accessed August 20, 2019, Doi: 10.1080/09540120500456656.

${ }^{73}$ Ibid., 220.

${ }^{74}$ Ibid., 221.
} 
for their best interests and 57 percent believed that the community would rather hurt them than help them. ${ }^{75}$

Based on these and other findings from youth-headed households in Rwanda, Thurman and colleagues suggest that community supports outside of biological family are central to recovery after genocide. "Taken together, these data suggest that family-centered interventions may not be ideal in this setting, thus interventions targeting villages are recommended." 76 While the authors of this study are referring to more traditional Rwandan villages, the foregoing discussion of emergent, topological Indigenous Villages in Canada indicates that there are emergent potentials to be explored further in Rwanda.

In Rwanda, like everywhere else in the world, "children and youth need a sense of belonging to their communities - to neighbors, family and friends who comprise the network of care, protection and identity in their lives. Social connection and emotional support are critical for survival."77 Some similar manifestations of the inter-generational trauma that has plagued Indigenous communities in Canada can also be seen among Rwandan youth. Many young people witnessed and experienced violence, were displaced from their homes and lost multiple family and friends. Additional complexities exist in family relationships since it is estimated that over twenty thousand children were born of rapes inflicted upon women during the 1994 genocide. $^{78}$

The Association des Etudiants et Éleves Rescapés du Genocide (AERG) is a community of genocide survivors organized based on a "New Family" kinship model which provides a powerfully unifying sensibility of coherence. AERG functions as an emergent organization that is understood by New Family members to be an important way for survivors to ensure their survival and shape their futures - as well as the future of Rwanda - in positive ways. ${ }^{79}$ This orientation is particularly significant when considering the self-reported size of AERG's national network. As described on the AERG official Rwandan website, "AERG is represented nationally at 41 Universities and institutes of higher learning and 484 secondary schools in Rwanda, with a total country-wide membership of 43,398." 80

AERG's New Families operate semi-autonomously in their day-to-day affairs while remaining connected through an overarching national body and numerous levels of state-involved bureaucracy. 81 At the local level New Families are comprised of small groups of between ten to fifteen male and female student survivors. Each New Family appoints a "mother" and "father" figure from their peer group with the rest of the group maintaining sibling-like relations. New Family parents help to mediate internal disputes and take care of the administrative work needed to facilitate the practical interface between family groups at the regional and national-level organizations. ${ }^{82}$

Each AERG family is made up of three types of members: 1). An effective member who is a survivor 2). An adhérent member who is a student but not a survivor, one who is sympathetic and wants to support AERG, 3). A member of honor, such as a university professor, a business person, or someone who is influential in the society. Someone to whom the organization can turn to for advice and moral support. "Outside these three categories, we have a sage, someone wellrespected, members of the family can seek advice from for a member's better future. The person is called parrain [godfather] or marrainne [godmother]." ${ }^{\prime 3}$

\footnotetext{
${ }^{75}$ Ibid., 226.

${ }^{76}$ Ibid., 227.

${ }^{77}$ Ibid.

${ }^{78}$ Standing Committee on Foreign Affairs and International Development and Canadian House of Commons, The Aftermath of the Rwandan Genocide: A Study of the Crisis of Children Born of Rape Committed during the Genocide: Report of the Standing Committee on Foreign Affairs and International Development (Ottawa: House of Commons, 2015).

${ }^{79}$ Arnold, A Psychological Investigation.

${ }^{80}$ Association of Student Genocide Survivors, accessed January 25, 2019, aerg.org.rw.

${ }^{81}$ Because of issues concerning anonymity I have changed the names of the Rwandan included in this paper.

${ }^{82}$ Evidently, the new family structure replicates heteronormative versions in its structure. The importance such heteronormative arrangement for state-management is discussed in Mark Rifkin, When Did Indians Become Straight?: Kinship, the History of Sexuality, and Native Sovereignty (New York: Oxford University Press, 2011).

${ }^{83}$ Jobb Arnold, interview by AERG member worker, July 3, 2008, Kigali, Rwanda.
} 
In addition to having survived the 1994 genocide many AERG members also grew-up in youth-headed households. As students, AERG members represent a relatively elite group of young people. They have faced difficult life circumstances, but in AERG they have found new sensibilities of coherence which provide the salutogenic supports needed to pursue their education. Many Rwandan youth do not have these opportunities, and in many communities of marginalized youth, the conditions of social death associated with trauma, addictions, stigma, and loneliness are pervasive ${ }^{84}$ Youth trying to manage parent-less households are put under enormous pressure to fill in the gaps left by biological families and traditional community-cultural connections. AERG emphasizes the importance of individuals fulfilling their responsibilities to their chosen families, communities, and country. In turn, the collective helps create safe spaces where individual AERG members can process their trauma.

New Families perpetuate salutogenic conditions insofar as they understand individual healing to be part of broader socially transformative processes that will eventually enhance the wellbeing of their entire group. In their organizational structure, AERG shares certain features with other community organizations formed by genocide survivors. In particular, among communities of Holocaust survivors in 1970s Israel, "Individual sense of coherence mattered less in the communal context" where shared supports that "protected the collective" were present. ${ }^{85}$ Among the day-today activities that typify New Family relations are acts of material mutual aid - such as sharing school supplies, or pooling funds - paired with ongoing emotional support. As one interviewee indicated, "If we see someone is worried because he doesn't have something, we tell him he doesn't have to feel bad for missing something, you can approach another member of the family and they help you." ${ }^{86}$

The sensibilities of coherence that are anchored to these chosen kinship networks also provide a grounded basis for outreach work. AERG members work with local elementary schools mentoring younger children and encouraging youth to work toward preventing genocide and building a collective future. In this sense, AERG mobilizes the affect connected to their genocidal experiences in ways that contribute to creating the conditions of pre-emergence for future generations following them. In ways that echo the work of Indigenous women described by Million, AERG surfaces their private feelings publicly to transform what could be a "debilitating force" of shame and social death "into a social change agent in their generation." ${ }^{87}$ New Families help youth to feel a sense of belonging based on trusting friendships and reliable networks that promote life and defend against social death. As one AERG interviewee put it,

We created the families so we can know each other well, and if one of us has problems, we can see how we can help them. There are some who live alone. When that person joins the family, he feels that he's not alone, he has someone else, another family.

In these families we have a father and a mother - the way it was before. We try to create these families so that we can feel we have parents, even though they are the same age, they are the big person, they take care of us. Some of us have parents who are widowers, they are left with nothing, they can't help their children - so these families try to do what they would be doing for their children. ${ }^{88}$

Chosen family structures in Rwanda have created spaces connected by relational webs based on individual experiences of trauma and oriented toward promoting peace and health among communities. After leaving the New Family formation at the end of their university studies, AERG

\footnotetext{
${ }^{84}$ Berthe Kayitesi, et al., "Facteurs de resilience chez des orphelins rescapes du genocide qui viven seuls dans les menage au Rwanda (Association Tubeho)," Canadian Journal of Community Mental Health 28, no. 1 (2009), 67-81.

${ }^{85}$ Aaron Antonovsky, et al., "Attitudes toward Retirement in an Israeli Cohort," The International Journal of Aging and Human Development 31, no. 1 (1990), 57-77, accessed January 10, 2019, Doi: 10.2190/A937-BUU4-DDHW-2CAU.

${ }^{86} \mathrm{Jobb}$ Arnold, interview by Alphonse, Jeanette, Berthe, Eugenine, and Gaston (AERG Family Members), July 11, 2007, Butare, Rwanda.

${ }^{87}$ Million, Felt Theory, 54.

${ }^{88}$ Jobb Arnold, interview by Alphonse, Jeanette, Berthe, and Gaston, July 11, 2007.
} 
members are able to re-integrate into communities and in so doing help disseminate elements of these salutogenic sensibilities of coherence. As a result, networks of interconnected New Families have contributed to the local conditions needed for healthy cultural adaptations to occur. These chosen families are altering the pre-emergent cultural conditions in Rwanda by generating significant networked-capacity for decentralized genocide prevention. AERG's New Family model is well suited to both combating forms of social death among its members, and also assembling webs of security that are adapted to survival in the volatile Great Lakes region where state-level relations and the alignment of regional military factions can change rapidly. ${ }^{89}$

\section{Ritualizing Emergent Community}

Of the three dimensions that characterize local sensibilities of coherence (comprehensibility, meaningfulness, and manageability) the struggle to re-establish deeply embedded cultural meaning is perhaps the most profound undertaking within these community groups. AERG members invest significant emotional energy into supporting other members of their New Families to pursue personal and public healing. These practices help to repair the ontological ruptures that the genocide has caused at all levels of society. The role of New Families is powerfully performed during ritualized mourning and burials for loved ones. Locating and burying the remains of loved ones killed in the genocide is a major issue in Rwanda where the connection to ancestor spirits is of great personal and cultural importance..$^{90}$ An AERG member described a burial ritual for a member of a New Family who had lost biological family in the genocide whose remains had never been recovered.

Recently a family member wanted his family buried officially, so we had to go there and help him with everything. Which means we helped in everything - at work, at home and with things that required money, and so the burial took place. So we sat with him after the burial, lit some fire, and even the neighbors could see that he had a family and they could join, and everything was cool. He lost a lot of his family members, but we don't know where they were buried, so we were there to bury people but they were not there. So we all sat together and talked about a lot of things, and all the neighbors joined in and we talked until the morning - and everyone could see that he had a family with him. ${ }^{91}$

Such publicly visible rituals are extremely important in rebuilding the bonds of community that genocides always target. Additionally, these public performances signal to others that these individuals are not marginal, or easily victimized, because their new families have their backs. The place-based and embodied nature of these practices highlight the profoundly emotional experience of mourning, as well as the affective power of mourning performed publicly. ${ }^{92}$

Traditional ceremonies and other rituals are also central to Winnipeg's urban Indigenous Village. ${ }^{93}$ Ritual gatherings integrate traditional Indigenous teachings and medicines such as sage and sweet grass in public spaces where communities are struggling with direct violence and social death. These ritualized spaces have become safe and accessible points of connection for people trying learn about their Indigenous culture and the legacies of colonialism. Local rituals help develop salutogenic sensibilities of coherence. Creating shared understandings, building relationships, connecting Indigenous youth to cultural teachings, and language skills are all important pre-requisites for community emergence. Champagne describes with detail his attention

${ }^{89}$ René Lemarchand, The Dynamics of Violence in Central Africa, (Philadelphia: University of Pennsylvania Press, 2009), accessed March 2, 2017, Doi: 10.9783/9780812202595.

${ }^{90}$ Laura Major, "Unearthing, Untangling and Re-Articulating Genocide Corpses in Rwanda," Critical African Studies 7, no. 2 (2015), 164-181, accessed May 2, 2016, Doi:10.1080/21681392.2015.1028206.

${ }^{91}$ Jobb Arnold, interview by Alphonse, Jeanette, Berthe, Eugenine, Gaston, July 11, 2007, Kigali, Rwanda.

${ }_{92}^{92}$ Judith Butler, Precarious Life: The Powers of Mourning and Violence (London: Verso, 2004).

${ }^{93}$ Jenna Liscious and Michael Redhead Champagne, "Street Ceremony and Activism: A North End Conversation," in Quest for Respect: The Church and Indigenous Spirituality, ed. Jeff Friesen and Steve Heinrichs (Winnipeg: Mennonite Church Canada, 2017) 
to the affective preconditions that enable people to connect with The Villages shared orientation and begin to feel part of a collective sensibility of coherence. The emotional intelligence of leaders like Champagne has been a key factor in the success of one of Winnipeg's longest running, independent, Indigenous-led community gatherings Meet Me at the Bell Tower.

Our style, our flavoring, our strategy, and our culture at Meet Me at the Bell Tower... has always been to create an environment before you deliver information. We have to create an environment where people are smiling, people are laughing, people feel good. Medicines are important for that. ${ }^{94}$ The children are important for that. They always set the tone right. Like having the smudge, having the drums, having the kids at the front end of everything we do at the Bell Tower. ${ }^{95}$

These ritualized community gatherings mobilize affective energies and transmit intergenerational knowledge needed for deeper and more sustainable forms social organization. Breaking colonial cycles and helping to re-align communities along clan-based teachings has become a transformative strategy. Winnipeg's Indigenous Village Model demonstrates how emergent organizing can help create pathways with alternative outcomes to the colonial present haunted by the "constant specter of Indigenous death." ${ }^{96}$ Villages are a basic unit for enacting modes of local governance that are in keeping with - not in opposition to - underpinning Indigenous ontologies. ${ }^{97}$ Again Champagne is succinct in his assessment. "I don't think the way Western institutions or Western culture raised people is conducive to responsibility-based leadership. And the Clan System is all about responsibility-based leadership."98

\section{Conclusion: Social Death is Incompatible with Salutogenesis}

Communities of genocide-impacted youth in both Canada and Rwanda continue to be leaders when it comes to community genocide prevention that displaces the conditions of social death and promotes forms of salutogenesis. These community groups have also been able to influence national level discourses in significant ways. In Rwanda, the state's dominant role in narrating collective memories continues to "shape notions of culpability and future possibilities for social change." 99 Brehm and Fox suggest that these state-level historical narratives have provided individuals with "a new lens to evaluate their nation's post-genocide progress," including shifting blame from individuals to institutions, especially those outside of Rwanda. ${ }^{100}$ While the historical narratives in both Rwanda and in Canada may well be shifting, these ideologically laden structures remain implicated in the production of social death either through processes of exclusion or indifference even as they do important work toward reconciliation. ${ }^{101}$

By focusing on the specific ways that local sensibilities of coherence mesh with the conditions of social death, this paper shifted the emphasis from state-level narratives to community practices that generate, promote, and sustain good health and social vitality. These local insights suggest that genocide prevention must increasingly work to identify and engage with the affective edges that serve as thresholds for local violence when they are still "in effect a pre-emergence." ${ }^{102}$ The prevention of social death requires a high level of contextual attunement to local economies of affect as well as sustained attentiveness and accountability to the ways that people's day-to-day

\footnotetext{
${ }^{94}$ Here Champagne is referring to traditional Indigenous medicines, primarily sage, sweet grass, cedar and tobacco.

${ }^{95}$ Champagne, discussion, December 12, 2015.

${ }^{96}$ Fuji, Killing 188; McCallum and Perry, Structures of indifference, 145.

${ }^{97}$ Sarah Hunt, “Ontologies of Indigeneity: The Politics of Embodying a Concept.” Cultural Geographies 21, no. 1 (2014), 27-32, accessed May 3, 2018, Doi:10.1177/1474474013500226.

${ }^{98}$ Champagne, discussion, December 12, 2015.

${ }^{99}$ Hollie Nyseth Brehm and Nicole Fox, "Narrating Genocide: Time, Memory, and Blame," Sociological Forum 32, no.1 (2017), 117, accessed November 2018, Doi: 10.1111/socf.12319.

${ }^{100}$ Ibid., 128.

${ }^{101}$ McCallum and Perry, Structures of indifference; Begley, Survivors get Gacacca.

${ }^{102}$ Williams, Marxism, 12.
} 
realities intersect with, and are impacted by, the conditions of social death. Members of Rwanda's local AERG network and Winnipeg's urban Indigenous Village, and countless other groups like them, are working to prevent genocide through contextually specific cultural adaptations that provide coherent ways for them to improve their own lives and the lives of their chosen families.

Genocide impacted communities in both Rwanda and Canada are still at risk because of unresolved genocidal preconditions that have been able to persist primarily due to state-level systemic contradictions. Locally however, community practices based on the principles of mutual aid, networked kinship, and grounded ritual are all emergent elements of, and coherent strategies for, creating healthy and sustainable futures that embrace the rich complexities and potentialities that are the essence of life.

\section{Acknowledgements}

This paper is dedicated to the memory of my friend Berthe Kayitesi and to all the survivors whose love and dedication to their chosen families and communities remains an inspiration. I gratefully acknowledge the Social Science Humanities and Research Council of Canada (SSHRC) as well as a postdoctoral fellowship with "The Affect Project: Memory, Aesthetics, Ethics" at the University of Manitoba, which allowed me to carry out portions of this research.

\section{Bibliography}

Aboriginal Youth Opportunities. "Meet Me at the Bell Tower." Accessed January 11, 2019. https:// www.ayomovement.com/mmbt.html.

Aboriginal Youth Opportunities, "Opportunities." Accessed January 10, 2019. https://www. ayomovement.com/.

Abu-Kaf, Sarah, Orna Braun-Lewensohn, and Tehila Kalagy. Youth in the Midst of Escalated Political Violence: Sense of Coherence and Hope among Jewish and Bedouin Arab Adolescents." Child and Adolescent Psychiatry and Mental Health 11, no. 1 (2017), 1-10. Doi: 10.1186/s13034-017-0178-Z

Ahmed, Sara. "Affective Economies." Social Text 51 (2004), 117-139.

Almedom, Astier M. "Resilience, Hardiness, Sense of Coherence and Post-traumatic Growth. All Paths Leading to "Light at the End of the Tunnel?" Journal of Loss and Trauma 10, no. 3 (2005), 253-265. Doi: 10.1080/15325020590928216

Astier M. Almedom, Berhe Tesfamichael, Zein Saeed Mohammed, Nick Mascie-Taylor, and Zemui Alemu. "Use of 'Sense of Coherence (SOC)' Scale to Measure Resilience in Eritrea: Interrogating both the Data and the Scale." Journal of Biosocial Science 39 (2007), 91-107. Doi: $10.1017 /$ S0021932005001112

Almedom, Astier M., Berhe Tesfamichael, Zein Saeed Mohammed, Jocelyn Muller, Nick MascieTaylor, and Zemui Alemu. "'Hope' Makes sense in Eritrean Sense of Coherence, but 'Loser' Does Not." Journal of Loss and Trauma 10 (2005), 433-451. Doi: 10.1080/15325020500193887

Almedom, Astier M., David O'Byrne, and Anne Jerneck, "Principles of Epistemological Accountability with Methodological Implications for Measuring, Assessing, and Profiling Human Resilience." Ecology and Society 20, no. 3 (2015). Doi: 10.5751/ES-07313-200309

Antonovsky, Aaron. Health, Stress, and Coping. London: Jossey-Bass Publishers, 1980.

"The Salutogenic Perspective: Toward a New View of Health and Illness." Advances 4, no. 1 (1987), 47-55.

Antonovsky, Aaron, Shifra Sagy, Israel Adler, and Rimona Visel. "Attitudes toward Retirement in an Israeli Cohort." The International Journal of Aging and Human Development 31, no. 1 (1990), 57-77. Doi: 10.2190/A937-BUU4-DDHW-2CAU

Arnold, Jobb. "Canada's Three Sovereignties and the Hope of Indigenous-Led Populism." In Surviving Canada: Indigenous Peoples Celebrate 150 Years of Betrayal, edited by Kiera Ladner and Myra Tait, 308-331. Winnipeg: Arbeiter Ring Publishers, 2017.

-. "A Psychological Investigation of Individual and Social Transformation in Post-Genocide Rwanda." In Confronting Genocide: Comparative Perspectives on Law and Justice, edited by René Provost and Payam Akhavan, 305-319. London and New York: Springer Press, 2011. 
Arquilla, John. "Of Networks and Nations." The Brown Journal of World Affairs 14, no. 1 (2007), 199-209.

Association of Student Genocide Survivors. Accessed January 25, 2019. http://aerg.org.rw/.

Azoulay, Ariella and Adi Ophir. "Abandoning Gaza." In Agamben and Colonialism, edited by Marcelo Svirsky and Simone Bignall, 178-203. Edinburgh: Edinburgh University Press, 2012.

Bagilishya, Deogratias. "Mourning and Recovery from Trauma: In Rwanda, Tears Flow Within." Transcultural Psychiatry 37, no. 3 (2000), 337-353. Doi: 10.1177/136346150003700304

Barta, Tony. "Relations of Genocide: Land and Lives in the Colonization of Australia." In Genocide and the Modern Age, edited by Michael N. Wallimann and Isidor Dobkowski, 237-252. Syracuse: Syracuse University Press, 2000.

Begley, Larissa R. "'Survivors get Gacaca, we get Nothing': Constructing Victimhood in Rwanda." In Narratives of Identity in Social Movements, Conflicts and Change, edited by Landon E. Hancock, 3-27. Bingley, UK: Emerald Press, 2016. Doi: 10.1108/s0163-786x20160000040002

Blackhawk, Ned. Violence Over the Land: Indians and Empires in the Early American West. Cambridge: Harvard University Press, 2008.

Blackstock, Cindy. "Reconciliation Means not Saying Sorry Twice: Lessons from Child Welfare in Canada." In From Truth to Reconciliation: Transforming The Legacy of Residential Schools, edited by M.B. Castellano, Linda Archibald, and Mike Degagne, 163-178. Ottawa: Dollco Printing, 2008.

. "Revisiting the Breath of Life Theory." The British Journal of Social Work 49, no. 4 (2019), 854-859. Doi: 10.1093/bjsw/bcz047

Brehm, Hollie Nyseth and Nicole Fox. "Narrating Genocide: Time, Memory, and Blame." Sociological Forum 32, no. 1 (2017), 116-139. Doi: 10.1111/socf.12319

Butler, Judith. Precarious Life: The Powers of Mourning and Violence. London: Verso, 2004.

Card, Claudia. "Genocide and Social Death." Hypatia: A Journal of Feminist Philosophy 18, no. 1 (2003), 63-79. Doi: 10.2979/HYP.2003.18.1.63

-------. "Surviving Long-Term Mass Atrocities." Midwest Studies in Philosophy 36, no. 1 (2012), 35-52. Doi: 10.1111/j.1475-4975.2012.00232.x

Chandler, Michael J. and Christopher Lalonde. "Cultural Continuity as a Hedge Against First Nations Suicides in Canada." Transcultural Psychiatry 35, no. 2 (1998), 191-219. Doi: $10.1177 / 136346159803500202$

Chrismas, Robert. "Modern Day Slavery and the Sex Industry: Raising the Voices of Survivors and Collaborators While Confronting Sex Trafficking and Exploitation in Manitoba, Canada." PhD diss., University of Manitoba, 2017. Accessed January 2, 2019. https:// mspace.lib.umanitoba.ca/bitstream/handle/1993/32586/CHRISMAS, Robert PHD THESIS. pdf? sequence $=45$.

Comack, Elizabeth. Racialized Policing: Aboriginal People's Encounters with the Police. Winnipeg: Fernwood Press, 2012.

Comack, Elizabeth, Jim Silver, Lawrence Deane, and Larry Morrissette. "Indians Wear Red": Colonialism, Resistance, and Aboriginal Street Gangs. Halifax: Fernwood Publishing, 2013.

Des Forges, Alison, Timothy Longman, and Jemera Rone. "Leave None to Tell the Story": Genocide in Rwanda. New York: Human Rights Watch, 1999.

Evans-Campbell, Teresa. "Historical Trauma in American Indian/Native Alaska Communities: A Multilevel Framework for Exploring Impacts on Individuals, Families, and Communities." Journal of Interpersonal Violence 23 (2008), 316-338. Doi: 10.1177/0886260507312290

Frankl, Victor E. Man's Search for Meaning: An introduction to logotheraphy, 4th ed. Translated by Ilse Lasch. Boston: Beacon Press, 1992.

Frazer, Ryan, and Bronwyn Carlson. "Indigenous Memes and the Invention of a People." Social Media Society 3, no. 4 (2017). Doi :10.1177/2056305117738993

Fuji, Lee Ann. Killing Neighbours: Webs of violence in Rwanda. Ithaca: Cornell University Press, 2009.

------. "Five Stories of Accidental Ethnography: Turning Unplanned Moments in the Field into Data." Qualitative Research 15, no.4 (2015), 525-539. Doi: 10.1177/1468794114548945

Giesbrect, Brian. "TRC Call to Action \#1: Child Welfare." Frontier Centre for Public Policy, November 4, 2018. Accessed January 5, 2019. https://fcpp.org/2018/11/04/trc-call-to-action-1-childwelfare/. 
Gould, Deborah B. Moving Politics: Emotion and ACT UP's fight against AIDS. Chicago: University of Chicago Press, 2009.

Gregg, Melissa and Gregory J. Seigworth. "An Inventory of Shimmers." In The Affect Theory Reader, eds. Melissa Gregg and Gregory J. Seigworth, 1-28. Durham: Duke University Press, 2010.

Harcourt, Bernard E. The Counterrevolution: How Our Government Went to War against Its Own Citizens. New York: Basic Books, 2018.

Hunt, Sarah. "Ontologies of Indigeneity: The Politics of Embodying a Concept." Cultural Geographies 21, no. 1 (2014), 27-32. Doi: 10.1177/147447401350022

Kayitesi, Berthe, Rollande Deslandes, and Christine Lebel. "Facteurs de Resilience Chez des Orphelins Rescapes du Genocide qui Viven Seuls dans les Menage au Rwanda (Association Tubeho)." Canadian Journal of Community Mental Health 28, no. 1 (2009), 67-81. Doi: 10.7870/ cjcmh-2009-0006

Kino-nda-niimi Collective, ed. The Winter We Danced: Voices from the Past, the Future, and the Idle No More Movement. Winnipeg: ARP Books, 2014.

Lemarchand, René. The Dynamics of Violence in Central Africa. Philadelphia: University of Pennsylvania Press, 2009.

Levi, Primo. The Drowned and the Saved. Translated by Raymond Rosenthal. Vintage Books: New York, 1986.

Leys, Ruth. "The Turn to Affect: A Critique." Critical Inquiry 37 (2011), 434-473.

Liscious, Jenna and Michael Redhead Champagne. "Street Ceremony and Activism: A North End Conversation." In Quest for Respect: The Church and Indigenous Spirituality, edited by Jeff Friesen and Steve Heinrichs. Winnipeg: Mennonite Church Canada, 2017.

Lindstrom, Bengt and Monica Eriksson. "Contextualizing salutogenesis and Antonovsky in Public Health Development." Health Promotion International 21, no. 3 (2006), 228-223. Doi: 10.1093/ heapro/dal016

--------. "Salutogenesis." Journal of Epidemiology and Community Health 59, no.6 (2005), 440-442.

Major, Laura. "Unearthing, Untangling and Re-Articulating Genocide Corpses in Rwanda." Critical African Studies 7, no. 2 (2015), 164-181. Doi: 10.1080/21681392.2015.1028206

Mamdani, Mahmood. When Victims Become Killers: Colonialism, Nativism, and the Genocide in Rwanda. Princeton: Princeton University Press, 2001.

McCallum, Mary Jane and Adelle Perry. Structures of Indifference: An Indigenous Life and Death in a Canadian City. Winnipeg: University of Manitoba Press, 2018.

Meierhenrich, Jens. "Introduction: The Study and History of Genocide." In Genocide: A Reader, edited by Jens Meierhenrich. Oxford: Oxford University Press, 2014.

Million, Dian. "Felt Theory: An Indigenous Feminist Approach to Affect and History." Wicazo Sa Review 24, no. 2 (2009), 53-76.

Moses, A. Dirk, ed. Empire, Colony and Genocide: Conquest, occupation, and Subaltern Resistance in World History. New York: Berghahn Books, 2008.

National Inquiry into Missing and Murdered Indigenous Women and Girls. Reclaiming Power and Place: The Final Report of the National Inquiry into Missing and Murdered Indigenous Women and Girls, Volume 1a. Accessed July 21, 2019. https://www.mmiwg-ffada.ca/wp-content/ uploads/2019/06/Final Report Vol 1a-1.pdf.

Nesdole, Robert, Debora Voigts, Rein Lepnurm, and Rose Roberts. "Reconceptualizing Determinants of Health: Barriers to Improving the Health Status of First Nations Peoples." Canadian Journal of Public Health 105, no. 3 (2014), 209-213. Doi: 10.17269/cjph.105.4308

Parker, John, Laura Jane Tiberi, Janetta Akhilgova, Farrukh Toirov, and Astier M Almedom. "“Hope Is the Engine of Life', 'Hope Dies with the Person': Analysis of Meaning Making in FAO Supported North Caucasus Communities Using the 'Sense and Sensibilities-of-Coherence' (SSOC) Methodology." Journal of Loss and Trauma 18, no. 2 (2013), 140-151. Doi:10.1080/15 $\underline{325024.2012 .684578}$

Rifkin, Mark. When Did Indians Become Straight?: Kinship, the History of Sexuality, and Native Sovereignty. New York: Oxford University Press, 2011.

Shields, Rob, Tonya K. Davidson, and Ondine Park, eds. Ecologies of Affect: Placing Nostalgia, Desire, and Hope (Waterloo: Wilfrid Laurier University Press, 2011). 
Short, Damien. Redefining Genocide: Settler colonialism, Social Death and Ecocide. London: Zed Books, 2016.

Short, Damien and Haifa Rashed. "Palestine." In Redefining genocide: Settler Colonialism, Social Death and Ecocide, edited by Damien Short, 68-92. London: Zed Books, 2016.

Snow, James. "Claudia Card's Concept of Social Death: A New Way of Looking at Social Death." Metaphilosophy 47, no. 4-5 (2016), 608-628. Doi: 10.1111/meta.12209

Sorge, Antonio and Jonathan Padwe. "The Abandoned Village? Introduction to the Special Issue." Critique of Anthropology 35, no. 3 (2015), 235-247. Doi: 10.1177/0308275X15588618

Standing Committee on Indigenous and Northern Affairs and Canadian Parliament. Breaking Point: The Suicide Crisis in Indigenous Communities: Report of the Standing Committee on Indigenous and Northern Affairs. Ottawa: House of Commons, 2017. Accessed November 2, 2018. http:// www.ourcommons.ca/Content/Committee/421/INAN/Reports/RP8977643/inanrp09/ inanrp09-e.pdf.

Standing Committee on Foreign Affairs and International Development and Canadian House of Commons. The Aftermath of the Rwandan Genocide: A Study of the Crisis of Children Born of Rape Committed during the Genocide: Report of the Standing Committee on Foreign Affairs and International Development. Ottawa: House of Commons, 2015.

Straus, Scott. The Order of Genocide: Race, Power, and War in Rwanda. Ithaca: Cornell University Press, 2006.

Suedfeld, Peter. "Reactions to Societal Trauma: Distress and/or Eustress." Political Psychology 18 (1997), 849-861. Doi: 10.1111/0162-895X.00082

--------. "Homo Invictus: The Indomitable Species." Canadian Psychology/Psychologie Canadienne 38, no. 3 (1997), 164-73. Doi: 10.1037/0708-5591.38.3.164

Tedeschi, Richard G., Crystal L. Park, and Lawrence G. Callhoun, eds. Post Traumatic Growth: Positive Change in the Aftermath of Crisis. New York: Psychology Press, 2008.

Thurman, Tonya R., Leslie Snider, Neil Boris, Edward Kalisa, Eleazer Nkunda Mugarira,Joseph Ntaganira, and Lisanne Brown. "Psychosocial Support and Marginalization of Youth-Headed Households in Rwanda." Aids Care 18, no. 3, (2006), 220-229. Doi: $\underline{10.1080 / 09540120500456656}$

Todd, Jennifer, Theresa O'Keefe, Nathalie Rougier, and Lorezo Canas Bottos. “Fluid of Frozen? Change in Ethno-National Identification in Contemporary Northern Ireland." Nationalism and Ethnic Politics 12 (2005), 323-346. Doi: 10.1080/13537110600882429

Truth and Reconciliation Commission of Canada. Final Report of the Truth and Reconciliation Commission of Canada: Honouring the Truth, Reconciling for the Future. Volume One. Toronto: James Lorimer \& Company Ltd., 2015.

Tufecki, Zeynep. Twitter and Tear Gas: The Power and Fragility of Networked Protest. New Haven: Yale University Press, 2017.

Tufecki, Zeynep and Christopher Wilson. "Social Media and the Decision to Participate in Political Protest: Observations from Tahrir Square." Journal of Communication 62 (2012), 363-379. Doi: 10.1111/j.1460-2466.2012.01629.x

United Nations. General Assembly Resolution 260, Convention on the Prevention and Punishment of the Crime of Genocide. December 9, 1948. UN Doc. A/RES/260(III).

Wacquant, Loïc, Tom Slater, and Virgílio Borges Pereira. "Territorial Stigmatization in Action." Environment and Planning 46 (2014), 1-11.

Williams, Raymond. Marxism and Literature. Oxford: Oxford University Press, 1977.

Woolford, Andrew. "Ontological Destruction: Genocide and Canadian Aboriginal Peoples." Genocide Studies and Prevention 4, no.1 (2009), 81-97. Doi: 10.1353/gsp.0.0010

Woolford, Andrew, Jeff Benvenuto, and Alexander L. Hinton, eds. Colonial Genocide in Indigenous North America. Durham: Duke University Press, 2014. 